\title{
The expression of foreign gene under the control of cauliflower mosaic virus 35s RNA promoter
}

\author{
Wang Hao and Bai Yongyan \\ Shanghai Institute of Plant Physiology, Academia Sinica. \\ 300 Fenglin Road, Shanghai 200032, China
}

\begin{abstract}
The promoter region of cauliflower mosaic virus (CaMV) 35s RNA was employed to construct an intermediate expression vector which can be used in Ti plasmid system of Agrobacterium tumefaciens. The original plasmid, which contains a polylinker between CaMV 35s RNA and its 3 ' termination signal in pUC18 was modified to have another antibiotic resistance marker (kanamycin resistance gene $\mathrm{Km}^{\mathrm{r}}$ ) to facilitate the selection of recombinant with Ti plasmid. Octopine synthase (ocs) structural gene was inserted into this vector downstream of CaMV 35s RNA promoter. This chimaeric gene was introduced into integrative $\mathrm{Ti}$ plasmid vector pGV3850, and then transformed into Nicotiana tobaccum cells. A binary plasmid vector was also used to introduce the chimaeric gene into tobacco cells. In both cases, the expression of ocs gene was demonstrated. The amount of octopine was much more than the nopaline synthesized by nopaline synthase (nos) gene transferred at the same time with Ti plasmid vector. This demonstrated that CaMV 35s RNA promoter is stronger in transcriptional function than the promoter of nos in tobacco cells.
\end{abstract}

Key words: Agrobacterium tumefaciens, gene expression, cauliflower mosaic Cirus 35s RNA promoter.

\section{INTRODUCTION}

During the past decade, extensive research on the Ti plasmid of Agrobacterium tumefaciens has brought development of useful and efficient vectors to introduce foreign genes into dicotyledonous plants. The system has taken advantage of the natural process by which A. Tumefacienstransforms plant cells. A. tumefaciens has 
been shown to transfer a small region of Ti plasmid into plant and the transferred DNA(T-DNA) integrates into plant chromosomes at different sites. Any gene inserted in T-DNA can thus be introduced into plant cells. Many vectors which contain chimaeric gene fusions with T-DNA have been constructed. The nos promoter, ocs promoter and CaMV promoters were used in these vectors to initiate transcription of bacterial genes and eukaryotic genes in the transformed plants[15].

Cauliflower mosaic virus is one of only a few doublestranded DNA viruses in plants. Its promoter directs the synthesis of $35 \mathrm{~s}$ RNA in infected plant cells. This promoter has been used for expression of various genes in transformed plants. Compared with the widely used plant transcriptional initiation signals used in vitro, such as nos promoter and ocs promoter, CaMV 35s RNA promoter was considered as the strongest one in model plants. Thomas Hohn et al. have constructed a vector which contains a polylinker between 35s RNA promoter and the 3 ' termination signal in pUC18[2]. They inserted foreign genes downstream of the promoter, and demonstrated transient expression of foreign genes in plant protoplasts. We modified this vector to construct an intermediate vector which can be used in Ti plasmid system. The new vector contains another antibiotic resistance marker, in addition to ampicillin resistant gene to facilitate the selection of recombinant with Ti plasmid. Using this vector, we introduced ocs gene into plant cells and detected its expression in transformed cells.

\section{MATERIALS AND METHODS}

1. Bacterial strains and plasmids used. (see Table 1)

Table 1. Bacterial strains and plasmids used

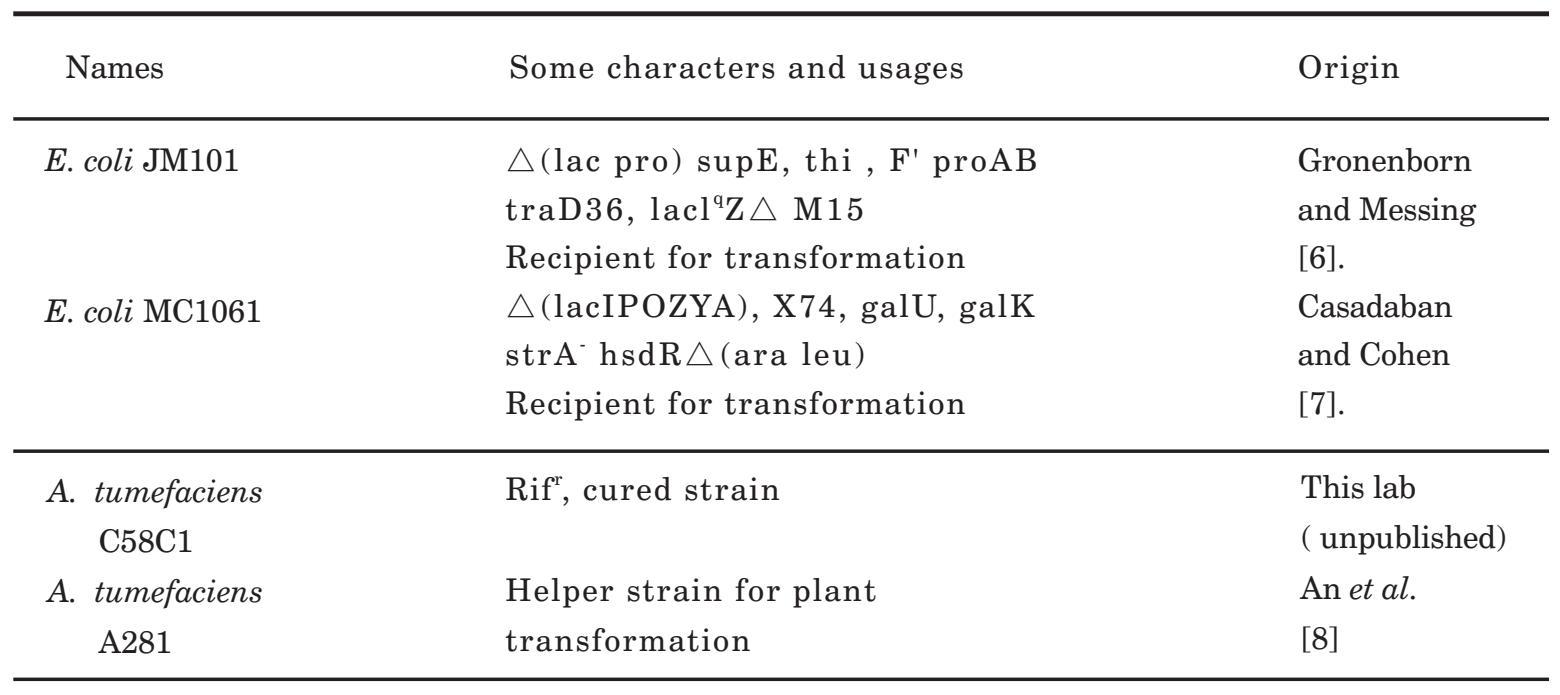




\begin{tabular}{|c|c|c|}
\hline $\mathrm{pKC7}$ & $\mathrm{Ap}^{\mathrm{r}}, \mathrm{Km}^{\mathrm{r}}$, Cloning vector & $\begin{array}{l}\text { Rao and } \\
\text { Roger }[9]\end{array}$ \\
\hline pDH51 & $\begin{array}{l}\mathrm{Ap}^{\mathrm{r}} \text {, Plasmid containing CaMV } \\
\text { 35s RNA promoter fragment. }\end{array}$ & $\begin{array}{l}\text { Thomas } \\
\text { et al. [ } 2 \text { ]. }\end{array}$ \\
\hline pNO1 & $\mathrm{Ap}^{\mathrm{r}}$, Plasmid containing ons gene & $\begin{array}{l}\text { Herrela- } \\
\text { Estrela[10]. }\end{array}$ \\
\hline pEND4K & $\mathrm{Km}^{\mathrm{r}}, \mathrm{Cm}^{\mathrm{r}}$, Binary plasmid vector & Klee[11]. \\
\hline pGV3850 & $\begin{array}{l}\mathrm{Ap}^{\mathrm{r}}, \text { Modified plant } \\
\text { transformation vector }\end{array}$ & $\begin{array}{l}\text { Zambryski } \\
\text { et al. [ } 12] .\end{array}$ \\
\hline pGJ28 & $\begin{array}{l}\mathrm{Km}^{\mathrm{r}} / \mathrm{Nm}^{\mathrm{r}} \text {, co1D replication } \\
\mathrm{Mob}+\text {, helper plasmid }\end{array}$ & $\begin{array}{l}\text { Van Haute } \\
{[13] .}\end{array}$ \\
\hline R64drd11 & $\begin{array}{l}\mathrm{Tc}^{\mathrm{r}} / \mathrm{Sm}^{\mathrm{r}} \text {, Iq, Tra }+ \\
\text { Helper plasmid }\end{array}$ & $\begin{array}{l}\text { Van Haute } \\
\text { [13]. }\end{array}$ \\
\hline pRK2073 & $\operatorname{Str}^{\mathrm{r}}$, helper plasmid & Ditta [ 14 ] \\
\hline
\end{tabular}

\section{Media}

LB medium[15] was used for E.coli. LB and AB minimum medium[16] were used for Agrobacterium tumefaciens. Plant tissue was grown on MS medium[17] with appropriate amount of relevant hormones.

\section{Enzymes}

Restriction enzymes and other enzymes were purchased from commercial sources and used according to the producer's recommendation.

\section{Isolation of DNA.}

Bacterial plasmid was isolated according to Birnboim and Doly[18]. Large scale isolation was done according to Maniatis et al.[19]. DNA sample was purified by ultracentrifugation in $\mathrm{CsCl}(1 \mathrm{~g} / \mathrm{ml})$ and ethidium bromide $(2.5 \mu \mathrm{g} / \mathrm{ml})$ solution at 400,00 rpm (rotor Ti50, Beckman L8$\mathrm{M}$ ultracentrifuge) for $40 \mathrm{hr}$. Agrobacterium total DNA was isolated according to Dhaese[20].

\section{Transformation of E. coli.}

Transformation of E.coli competent cells was done according to Maniatis et al. [21].

\section{Plasmid mobilization from E. coli to Agrobacterium.}

The plasmid was mobilized from E. coli to Agrobacteria according to Van Haute et al. [13].

\section{DNA Hybridization}

Southern transfer was done according to Southern et al.. DNA probe was labeled by nick translation with ( $\left.a{ }_{-}^{32} \mathrm{p}\right)$ ATP (From Amersham).

\section{Plant tissue transformation.}

Plant transformation was done according to Tang Ti et al. (to be published in Acta Phytophy- 
siologia Sinica). After leaf was sterilized, lower epidemis of Nicotiana tobaccum was torn off and leaf pieces were put on MS medium containing cefotaxime $(0.5 \mathrm{mg} / \mathrm{ml})$ and $6 \mathrm{BA}(1 \mu \mathrm{g} / \mathrm{ml})$. Then a few drops of overnight bacterial suspension culture were applied to leaf surface. The plant tissue was incubated at $28^{\circ} \mathrm{C}$.

\section{Opine assay.}

Opine was detected by a modified method from Otten et a1.[22]. Plant tissue was cut into small pieces and incubated in an assay buffer [Arginine (0.05M), $\mathrm{Na}_{2} \mathrm{HPO}_{4} / \mathrm{NaH}_{2} \mathrm{PO}_{4}$ (0.1M, pH 7.0)] at $28^{\circ} \mathrm{C}$ overnight. The tissue was ground and then centrifuged at 8,000 rpm. The supernatant was used for opine assay.

\section{RESULTS}

\section{Construction of intermediate vector $p B W 1$.}

Part of the sequences between the left border and right border of T-DNA was replaced by pBR322 sequence in modified Ti plasmid vector pGV3850. Those intermediate vectors that contain pBR322 sequence can integrate into pGV3850 by homologous recombination. Because there is an ampicillin resistance marker in pGV3850 itself, it would be better that the intermediate vector had another antibiotic resistance marker to select for the recombinant. We used $\mathrm{Km}^{\mathrm{r}}$ in $\mathrm{pKC} 7$ as such a selective marker. We first digested pKC7D with SalI and self-ligated with T-DNA ligase to get plasmid pKC7D which contains no BamHI site and is more convenient for future cloning. Then we inserted the EcoRI fragment containing $35 \mathrm{sRNA}$ promoter and terminator from pDH51 into EcoRI site of pKC7D to get the intermediate vector pBW1 (Figs. 1,2,3).

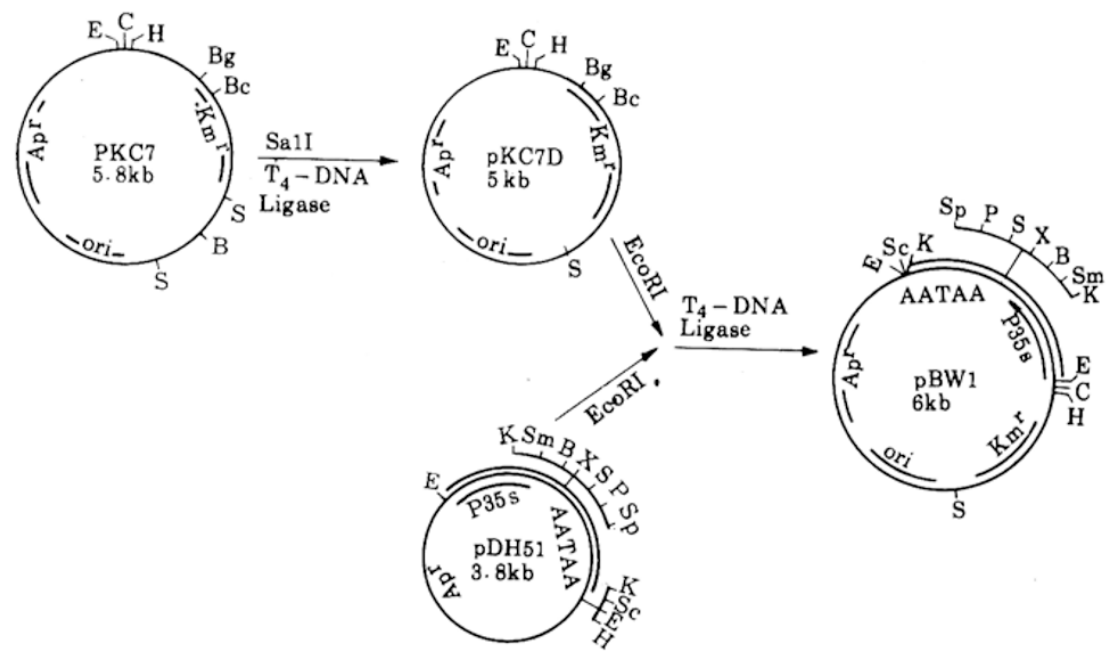

Fig. 1 Construction of pBW1.

pKC7 was digested with SalI and self-ligated with $\mathrm{T}_{4}$-DNA ligase. The recombinant plasmid, pKC7D, contains no BamHI site. The EcoRI fragment from pDH51 containing CaMV $35 \mathrm{~s}$ RNA promoter was then inserted into the EcoRIsite of pKC7Dtoget pBW1. B. BamH I; Bc, Bcl I; Bg, Bgl II; C, ClaI; E, EcoR I: H, HindIII; K, Kpn I; P, Pst I; S.Sal I; Sc, SacI; Sm, SmaI; Sp, SphI; X, XbaI. 

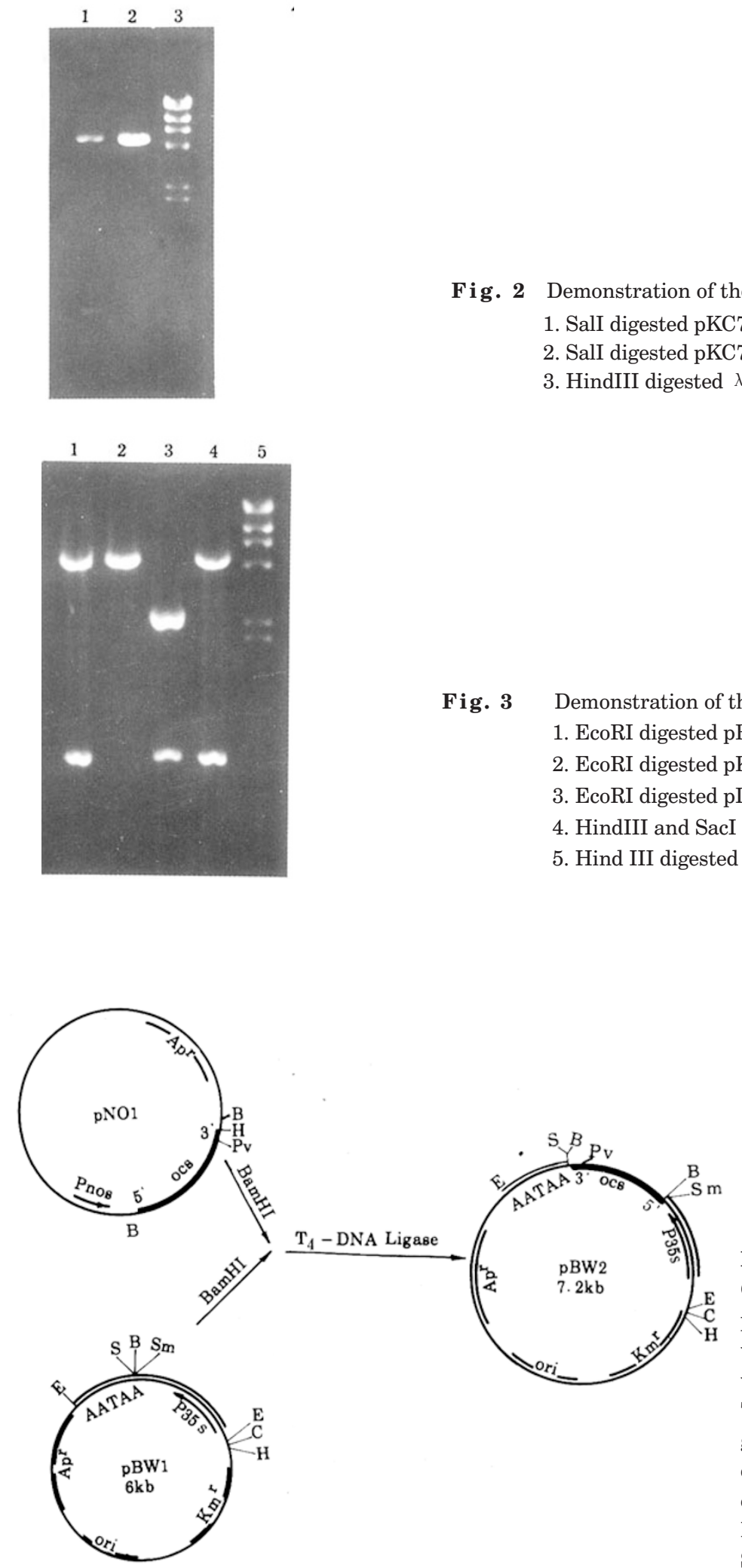

Fig. 3 Demonstration of the construction of pBW1.

1. EcoRI digested pBW1.

2. EcoRI digested pKC7D.

3. EcoRI digested pDH51.

4. HindIII and SacI digested pBW1.

5 . Hind III digested $\lambda$ DNA.
Fig. 4

Construction of pBW2.

pNO1 and pBW1 were digested with BamHI and then ligated with $\mathrm{T}_{4}$-DNA ligase.

The recombinant plasmid was digested with PvuII and SmaI to determine the orientation of the ocs gene. B, BamHI: C, ClaI; E, EcoRI; H, Hind III; Pv, PvuII; S, SalI; Sm, SmaI. 
CaMV 35s RNA promoter directed foreign gene expression

\section{Construction of CaMV 35s-ocs chimaeric gene.}

In order to study the expression of foreign gene under the control of $35 \mathrm{~s}$ RNA promoter, octopine synthase structural gene was inserted downstream of the promoter in pBW1. The pNO1 plasmid containing ocs gene was digested with BamHI and the resulted $1.2 \mathrm{~kb}$ fragment was inserted into BamHI site of pBW1. The orientation of ocs was examined by digestion with PvuII and SmaI, because there is a PvuII site near the 3 ' end of the ocs gene (Figs. 4,5).

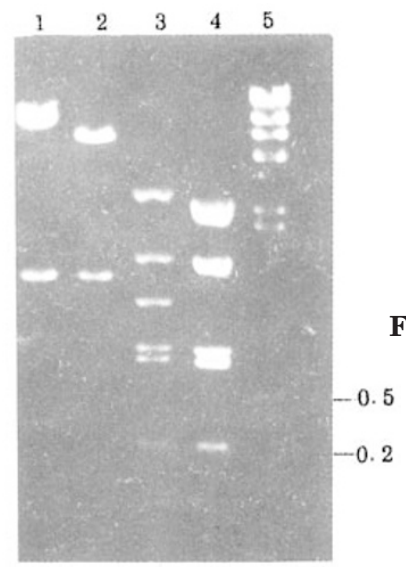

Fig. 5 Demonstration of construction of pBW2.

1. BamHI digested pNO1.

2. BamHI digested pBW2.

3. PvuII and SmaI digested pBW2.

4. PvuII and Sina I digested pBW1.

5 . Hind III digested $\lambda$ DNA.

\section{Mobilization of plasmid pBW2 into A. tumefaciens and transformation of plant}

\section{tissue.}

Plasmid pBW2 was mobilized into A tumefaciens C58C1 (pGV3850) with the help of plasmid pGJ28 and R64drd11, and integrated into Ti plasmid pGV3850. The transconjugant was selected on LB medium containing ampicillin (100 mg/l), kanamycin $(100 \mathrm{mg} / \mathrm{l})$ and rifampicin $(50 \mathrm{mg} / \mathrm{l})$. Using ocs genefragment as probe, we have detected the ocs gene in the transconjugant total DNA (Fig. 6).

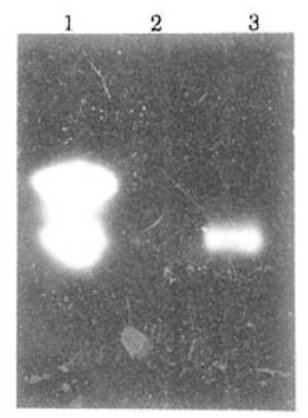

Fig. 6 Southern analysis of DNA from Agrobacterium C58 (pBW2::pGV3850) The probe was BamHI fragment from pNO1.

1. pNO1 digested with BamHI.

2. DNA from C58 (pGV3850 digested with BamHI.

3. DNA from C58 (pGV3850::pBW2) digested with BamH I.

The Agrobacterial suspension culture was used to transform tobacco leaves Shoots grow at the sites of inoculation after three weeks of cultivation on MS medium containing cefotaxime $(0.5 \mathrm{mg} / \mathrm{ml})$ and $6 \mathrm{BA}(1 \mu \mathrm{g} / \mathrm{ml})$. Octopine and nopaline 
were detected in some shoots. The ammount of octopine detected is much more than that of nopaline (Fig. 7).

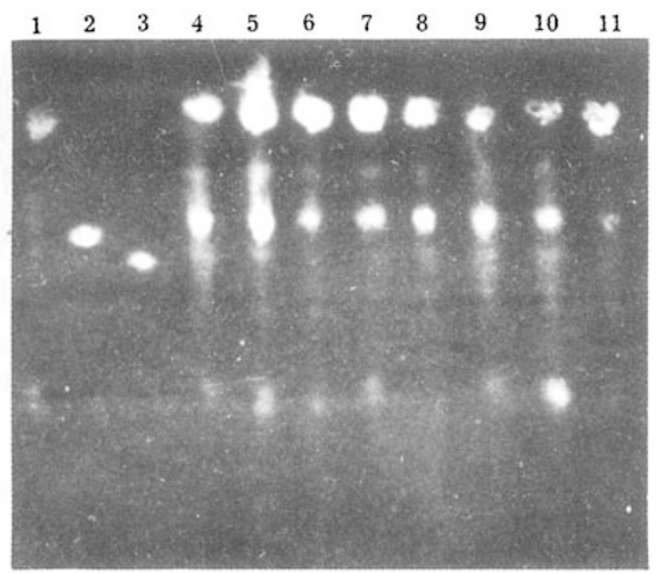

Fig. 7 Detection of octopine and nopaline.

1. Untransformed plant tissue.

2. Standard octopine.

3. Standard nopaline.

4-11. Transformed plant shoots.

\section{Transformation of plant with binary plasmid vector.}

We cloned the chimaeric 35s-ocs gene between T-DNA borders in binary plasmid pEND4K which contains chimaeric nos-NTPII gene highly expressed in plants. pBW2 was digested with Sal I and inserted into the unique SalI site in pEND4K to get plasmid pBW3 (Fig.8). pBW3 was mobilized into Agrobacterium A281 (pTiBo

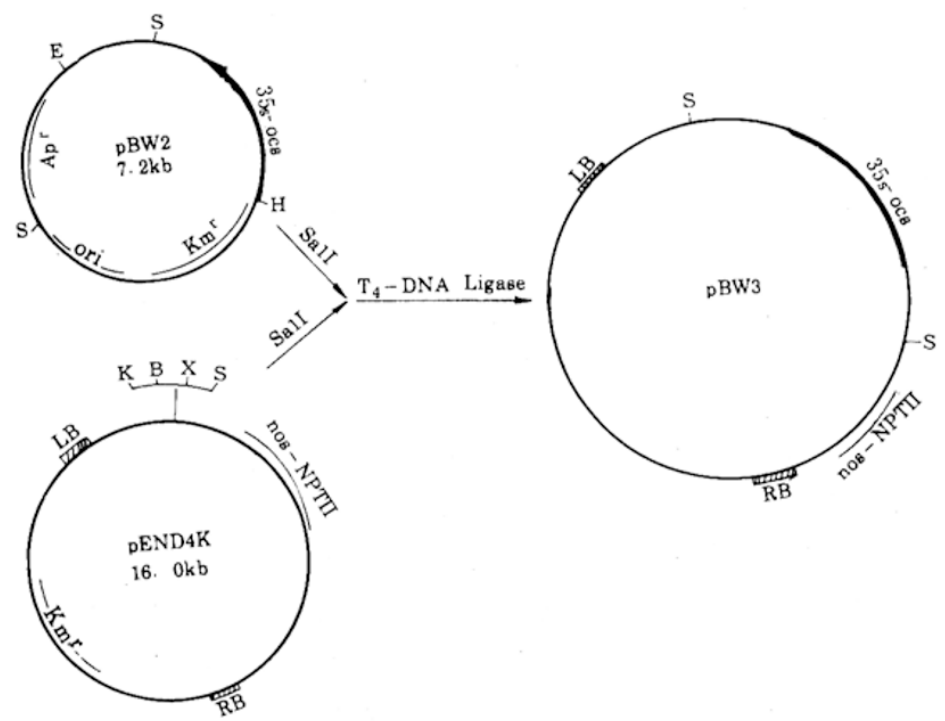

Fig. 8 Construction of pBW3.

pBW2 was digested with Sal I and ligated with Sal I digested pEND4K to get pBW3. B, BamHI; E, EcoRI: K, KpnI; S, Sal I; X, XbalI: LB, left border; RB, right border. 
542) by the help of plasmid pRK2073 via triparential procedure [13]. The bacterium was selcted on $\mathrm{AB}$ minimum medium containing ampicillin (100 $\mathrm{mg} / \mathrm{l})$ and $\mathrm{ka}-$ namycin $(100 \mathrm{mg} / \mathrm{l})$. The presence of pBW3 in the Agrobacterium cells was confirmed by plasmid minipreparation (data not shown).

Overnight culture of A281 (pTiBo542, pBW3) was used to transform plant leaves. Calli formed on the surface of the leaves after 10 days of cultivation on MS medium containing cefotaxime and 6BA. The calli were then transferred to MS medium containing no hormone but kanamycin. After 10 days, shoots formed and half of them were albinous and died soon, but others were green and normal. After the green shoots were transferred to fresh medium of the same composition for more than a week, we used them for octopine and nopaline assay and found that all of the kanamycin resistance shoots produced octopine (Data not shown).

\section{DISCUSSION}

We report the results of experiment designed to introduce foreign gene into plants, to get them expressed and to regenerate plants directly from the transformed tissue. With the development of Ti plasmid as plant transformation vector, it's no longer difficult to introduce genes into dicotyledonous plants. Since not all foreign genes inserted into plant genome will carry apromoter functional in plants, plant recongnizable promoter is required for the expression of foreign genes.

The nos promoter was used to direct the expression of bacterial genes including some economically useful genes. CaMV 35s RNA promoter was also used extensively. Ti plasmid vector pGV3850 contains a nos gene in its modified T-DNA region. This nos gene was transferred to plant cells at the same time with foreign chimaeric gene. Fig. 7 shows the detection of octopine and nopaline in transformed plant cells. The octopine synthesized by chimaeric gene was much more than the nopaline synthesized by nos gene. This demonstrates that the CaMV 35s RNA promoter is stronger than that of nos. This character of CaMV 35s RNA promoter will be benefitial to us when we try to make foreign genes highly expressed.

We used both integrative and binary Ti plasmid vectors to introduce chimaeric gene into plant cells. In the first case, we used nos gene as a marker to select the transformed cells. This selection method is time consuming. When we used the binary plasmid vector pEND4K, which contains a chimaeric nos-NTPII gene, transformed plant cells were kanamycin resistance. All the shoots resistance to kanamycin produced octopine. While in the first case, we used no kanamycin as a selective marker, less than $10 \%$ of the shoots examined produced octopine. 


\section{REFERENCES}

[1] Fromm M, Taylor LP, Walbot V. Expression of genes transferred into monocot and dicot plant cells by electroporation. Proc Natl Acad Sci USA 1985;82:5824-5828.

[2] Pietrazak M, Shillito RD, H Thomasand Potrykus I.Expression in plants of two bacterial resistance genes after protoplast transformation with a new plant expression vector. Nucleic Acid Research vol 14. 1986; 14:5857-5868.

[3] Ow DW, Wood KV, Deluca M, de Wet J, Helinski H, Howwell H. Transient and stable expression of the firefly luciferase gene in plant cells and transgenic plants. Science 1986:232:856-859.

[4] Beavan MW, Mason SE, Goelet, P. Expression of tobacco mosaic virus coat protein by a cauliflower mosaic virus promoter in plants transformed by Agrobacterium. The EMBO J 1986;(4)8:1921-1926.

[5] Abel PP et al. Delay of disease development in transgenic plants that express the tobacco mosaic virus coat protein gene. Science 1986;232:738-742.

[6] Groneborn B. and Messing J. Methylation of single-stranded DNA in vitro introduces new restriction endonuclease cleavage sites. Nature $1978 ; 272: 375$.

[7] Casadaban, Cohen S. Analysis of gene control signals by DNA fusion and cloning in Escherichia coil. J Mol Biol 1980;138:179.

[8] An G, de Wet JR, Wood RV, Deluca M, Helinski DR. New cloning vehicles for transformation of higher plants. The EMBO J 1986;4:277-284.

[9] Rao RN, Rogers SG. Plasmid pKC7: A vector containing ten restriction endonuclease sites suitable for cloning DNA segments. Gene $1979 ; 7: 79$.

[10] Herrera-RstrellaL et al. Expression of chimaeric genes transferred into plant cells using a Ti plasmid-derived vector. Nature 1983;303:209-213.

[11] Klee H J, Yanofski MF, Nester E. Vectors for transformation of higher plants. Bioteehnology $1985 ; 3: 637-642$.

[12] Zambryski P, Joos H, Genetelle C, Leemens J, Montagu MV, Schell J. Ti plasmid vector for the introduction of DNA into plant cells without alternation of their normal regeneration capacity. The EMBO J 1983;2:2143-2150.

[13] Van Haute E, Joos H, Maes M, Warren G, Van Montagu M, Schell J. Intergenie transfer and exchange recombination of restriction fragments cloned in pBR322: A noval strategy for the reversed genetics of the Ti plasmid of Agrobacterium tumefaciens. The EMBO J $1983 ; 2: 411-417$.

[14] Ditta G, Stanfield S, Corbin D, Helinski DR. Broad host range DNA cloning system for gram-negative bacteria:Construction of a gene bank of Rhizobium melilot. Proc Natl Acad Sci USA 1980;77:7347-7351.

[15] Miller JII. Experiments in molecular genetics. New York: Academic Press, Cold Spring Harbor Laboratory, 1972:93-94.

[16] Chilton MD, Currier T, Farrand S, Bendich A, Gordor M, Nester E. Agrobacterium tumefaciens DNA and PS8 bacterial phage DNA not detected in crown gall tumors. Proc Natl Acad USA 1974;71:3672-3678. 
CaMV 35s RNA promoter directed foreign gene expression

[17] Murashage T, Skoog F, A revised medium for rapid growth and bioassay with tobacco tissue culture. Plant Physiol 1962; 17:620-635.

[18]Birnboim HC, Doly J. A rapid alkaline extraction procedure for screening recombinant plasmid DNA. Nucleic Acid Res 1979;7:1513.

[19] Maniatis T, Fritsch EF, Sanbrook J. In "molecular cloning, a Laboratory Manual". Cold Spring Harbor Laboratory, 1982: 93-94.

[20] Dhaese P. Rapid mapping of transposon insertion and deletion mutations in the large TiPlasmids of Agrobacterium tumefaciens. Nucleic Acid Res 1979 ;7:1837- 1849.

[21] Maniatis T, Fritsch EF, Sambrook J. In "molecular cloning, a Laboratory Manual". Cold Spring Harbor Laboratory, 1982:252-253.

[22] Otten LABM, Schiperoort RA. A rapid microscale method for the detection of lysopine and nopaline dehydrogenase, activities. Biochem Biophy Acta 1978;527:497-500.

Received 24-7-1988. Accepted 13-12-1988. 